\title{
Emerging and re-emerging diseases - the threat continues
}

\author{
Andrei Vata, Carmen Dorobat, Luminita Gina Vata, Catalina Mihaela Luca \\ "Grigore T. Popa" University of Medicine and Pharmacy, Iasi, Romania
}

\begin{abstract}
Infectious diseases have accompanied human development from the earliest times and have often influenced it greatly. Although they were considered "an endangered species" in the second half of the 20th century, they continue to pose a serious threat to individual or public health. Diagnosis technique improvement, climate changes, increased population mobility and vaccine cover decrease are only some of the factors that have contributed lately to the occurrence and fast spreading of new pathogens or to the re-emerging of diseases already considered historical. Most of these infectious agents (Zika, Ebola, Chikungunya, MERS, SARS, new influenza viruses), for which there are few therapeutic resources, were the cause for regional or global epidemic outbreaks, which generated concern among healthcare professionals and often panic in the population, as well as significant economic losses. The international and medical communities joined their forces and got financially and logistically involved, sometimes paying with their own lives, in fighting these new threats. The fast understanding of the epidemiological process, pathogenesis and development of diagnosis and prevention methods has often helped limit the spread of emerging diseases and has laid the grounds for their future control.
\end{abstract}

Keywords: arbovirus, epidemic, zoonoses, infection

Infectious diseases have accompanied human development from the earliest times and have often influenced it greatly. Most scientists agree that the first bacteria emerged on Earth about 3 billion years ago (1), whereas the first intelligent humans date back to 100,000 years at the most (2). Nevertheless, we only found out about the existence of these living creatures invisible to the naked eye in the $17^{\text {th }}$ century, when Anton van Leeuwenhoek, a rich cloth merchant, invented the first optical microscope designed to help him check the quality of the fabrics that he sold (3). This was not enough for the medical world to realize the importance of the discovery of the Dutch merchant. Two more centuries were necessary for the theory of the "spontaneous generation" (4) of diseases to be forgotten due to the discoveries of the founding fathers of microbiology, who showed that bacteria, small, yet diverse and extremely well organized creatures, were the cause of a large number of diseases - the infectious diseases.
For a rather long time, doctors did not have efficient weapons to fight these diseases, until the discovery and large scale production, after the Second World War, of the first antibiotic - penicillin. Things then evolved rather quickly, with the emergence on the market of many other classes of active antibiotics against an increasing number of bacteria (5). Thus, in the 1970's, due to the wide range of available antibiotics, to bacteria with no significant acquired resistance and to the good response to the massive vaccination campaigns conducted at that time, many specialists predicted a short life to infectious diseases and were virtually convinced of their disappearance (6). Nonetheless, nowadays, almost half a century later, not only did they not disappear, but, on the contrary, at least 3 of the 10-major mortality causes of the first decade of the $21^{\text {st }}$ century have had an infectious cause (pneumonia, acute diarrheic disease, HIV); moreover, some of them have become increasingly important (7). 
Why did this happen? Because pathogenic microorganisms have their own intelligence and ability to adjust to our various microbicidal weapons, and because humans are sometimes not so intelligent and abuse this arsenal in human and veterinary medicine, as well as in agriculture. Furthermore, we discover new infectious agents, or realize that older, already known diseases have infectious origins.

The definition of emerging (E) or re-emerging (RE) diseases varies. A disease is said to be emerging if its incidence has increased over the last 20 years or is expected to increase in the near future due to the occurrence of a new infectious agent or to the discovery of an infectious disease of an already known disease (8). Morse (9) has a different approach and sees emergence as the occurrence of a new infection in a population or the rapid increase of the incidence or geographic spread of an already known infection. Reemergence is the reoccurrence of a known disease, which was considered eradicated or under control.

The causes of $\mathrm{E}$ and $\mathrm{RE}$ diseases are numerous and often complex: conurbations make disease transmission much easier, increased population mobility facilitates the extremely rapid spread of infectious diseases as we have witnessed on many occasions in the recent past. Climate changes and insect environment changes allow these vectors to extend their survival and associated disease transmission area. We should also mention here antibiotic resistance, vaccine coverage decrease, lack of hygiene standards and many other contributing factors.

Looking back at the last 20 years, one may notice that starting with 2008 there was at least one emerging pathogen per year (Table 1).

Among the re-emerging diseases we may list: malaria, measles, tuberculosis, cholera, whooping cough, diphtheria, plague, multi-resistant bacteria infections: S. aureus, Ps. aeruginosa, K. pneumomiae, E. coli and many more.

What is the origin of ED?

It is currently thought that about 1400 species of human pathogens have been discovered, $60 \%$ of which are transmitted from animals, $10 \%$ by environmental factors and the rest exclusively among humans (10).

When referring strictly to ED, $73 \%$ of them are zoonoses (SARS, Nipah, Ebola etc.), and this per-
TABLE 1. Emerging infections over the last 20 years

\begin{tabular}{|c|l|}
\hline Year & Pathogen/Disease \\
\hline 2015 & $\begin{array}{l}\text { Ebola } \\
\text { Zika }\end{array}$ \\
\hline 2014 & D68 enterovirus \\
\hline 2013 & $\begin{array}{l}\text { A/H7N9 influenza } \\
\text { Chikungunya }\end{array}$ \\
\hline 2012 & $\begin{array}{l}\text { Middle East respiratory syndrome (MERS) Borreliosis } \\
\text { coronavirus }\end{array}$ \\
\hline 2011 & Escherichia coli 0104:H4 \\
\hline 2010 & Huaiyangshan virus, (SFTS) \\
\hline 2009 & A/H1N1pdm09 influenza \\
\hline 2008 & $\begin{array}{l}\text { Plasmodiumknowlesi } \\
\text { Lujo virus }\end{array}$ \\
\hline 2005 & Human HTLV3, HTLV4 retroviruses \\
\hline 2004 & $\begin{array}{l}\text { A/H5N1 influenza } \\
\text { Nipah virus }\end{array}$ \\
\hline 2003 & SARS coronavirus \\
\hline 2000 & C. difficile Bl/NAP1/027 \\
\hline 1996 & West Nile virus \\
\hline
\end{tabular}

centage has been increasing lately. A significant part is represented by diseases transmitted by vectors - almost one third (22.8\%) (10).

$\mathrm{E}$ and RE diseases have long ceased to be a mere regional problem in tropical or underdeveloped areas, as they emerged or spread rapidly throughout the world.The number, diversity and concentration of human pathogens increase as we approach the Equator, probably due to environmental factors (humidity, temperature) supporting their transmission and multiplication. Nevertheless, this is not the case with ED, most of which originate in NE USA, in Western Europe, Japan, Asia, SE Australia (11).

The most well-known emerging arboviroses (ARthropod-BOrne virus) are generated by the West Nile, Chikungunia, Denga, Zika or Huaiyangshan viruses.

West-Nile virus infection is one of the most common arboviroses in the world, being transmitted by the Culex mosquitoes, which are also very common in Romania and for which humans are only an accidental host.

Its spread in Europe has been known as early as the 1960 's, most of the infections being asymptomatic $(80 \%)$ or generating an undifferentiated febrile disease.

However, the summer of 1996 witnessed in Romania one of the biggest epidemics ever known of meningo-encephalitic forms of West-Nile infection, with over 800 cases (393 laboratory confirmed) and 17 deaths (12). 
Similar outbreaks followed in New York (62 cases, 1 dead) in 1999 (13), Israel (417 confirmed cases, 33 dead) in 2000 (14), Canada (1494 cases, 14 dead) in 2003 (15), USA (663 cases, 335 meningo-encephalitis cases, 32 dead) in 2009 (16) and, closer to us, in Greece (262 cases, 35 dead) in 2010 (17).

After the 1996 events, Romania set up a surveillance system devoted to this disease in the National Center for Communicable Disease Surveillance and Control, which reported sporadic cases: 82 neuro-meningeal forms between 1997 and 2004, 2 in 2008, 3 in 2009, with a peak in 2010 - with 54 confirmed cases $(18,19)$. The latest report of the NCCDSC (November 2016) shows 93 confirmed cases and 11 deaths caused by West-Nile (20).

Chikungunya is a virus isolated in Tanzania in 1952, the name of which derives from the local Kimakonde dialect and means "to contort". The clinical manifestations of the infection resemble influenza, with a 7-to-10-day incubation period, and gastrointestinal, cardiovascular or nervous (meningo-encephalitis) complications. Deaths have been reported in the elderly or in patients with comorbidites (21).

The disease is transmitted by the Aedes aegypti mosquitoes by daytime bites (which used to be present in Europe, but has now disappeared) and the Aedes albopictus mosquitoes, which still exists in southern Europe and the existence of which has also been recently reported around Bucharest (21, 22).

After the first cases reported in eastern Africa in the 1950 's, the infection spread relatively rapidly and is now present on all the continents, including in Europe. The first major epidemic outbreaks occurred in the Indian Ocean islands between 2001 and 2007, with over 100,000 cases in the Réunion Island and over 1 million in India $(23,24)$. In 2007 , the virus reached Europe, more precisely northern Italy, where 247 cases were confirmed and one died (25) (it seems that the virus was transmitted by an Indian on a business trip). In France, the first case of indigenous transmission occurred in 2010, and another 14 cases were reported by 2014 (26). Since 2013 the disease has been also present in America (Brazil, Mexico, Columbia), including in the USA (Florida) (27).
Dengue has been known in Chinese medicine since the $10^{\text {th }}$ century (28), whereas the first "modern" epidemics were reported around the Equator in the $18^{\text {th }}$ century (29). It is another disease transmitted by mosquitoes (Aedes family), the main reservoir of which is man and different species of monkeys. As far as its importance is concerned, it is considered the second mosquito-transmitted disease in the world (after malaria), as it has spread in over 110 countries (30), generally between the $30^{\circ}$ $\mathrm{N}$ and $40^{\circ} \mathrm{S}$ latitudes. Starting with the 1950's, a severe form of the disease has been reported, with hemorrhagic manifestations, especially in children (hemorrhagic dengue), which causes over 20,000 deaths per year (31).

Many infections are asymptomatic (40-80\%). Often the infection produces manifestations resembling influenza. Sometimes, a severe form or dengue shock ( $<5 \%$ of all the cases, especially children and adolescents) with increased capillary permeability may determine life-threatening hypovolemic shock and high mortality rates (31).

The number of dengue cases has increased worldwide during the last decades (from about 1,000 in the 1950's to 1 million between 2,000 and 2007), just like the geographical area of its spread. About 2.5 billion people (2/5 of the word population) are currently exposed to the dengue risk (29). Disease prevalence estimations range between 50 and 90 million cases each year, of which up to 76 million (67-136 million) are clinically manifest (31).

In Europe, the latest epidemic occurred in Greece in the 1920's, and imported cases have been reported since. Between 2008 and 2012, their number reached 4,000 (of which 6 in Romania). In the entire EU, the number of cases doubled in 2012 as compared to 2011 (32). The latest epidemic on the quasi-European territory was in Madeira, an island in the Atlantic Ocean under Portuguese administration, in 2012, with over 2,000 probable cases $(1,000$ confirmed). The disease also affected the tourists, who later exported the disease to $13 \mathrm{EU}$ countries. One of these cases even reached our hospital in Iasi City. There were no deadly cases reported (33).

Zika virus has made it to the front page of newspapers and has been the focus of attention of the medical community since the beginning of 2016. It has been known since 1947, the first hu- 
man infection being described in Nigeria, in 1954 (34). Until 2007, it seems that there were only small African sites of infection. The first important epidemic outbreak was reported in 2007 , when $73 \%$ of the population of Yap island was infected (35). The disease then rapidly spread in the entire region and many successive epidemics occurred (36). The first cases in South America were reported in Brazil, in May 2015, with over 1 million suspected cases reported so far. It then spread to other 29 American countries. Only imported cases have been reported in Europe and Canada so far (37).

The virus is transmitted mainly by Aedes (Ae. aegypti, Ae. africanus, Ae. hensilli, andAe. Albopictus) mosquito bites. The virus can survive up to 60 days in the mosquito body, and the reservoir of infection is represented by monkeys and other species of wild and domestic animals, in addition to humans. Inter-human transmission (from mother to fetus, by sexual intercourse and possibly by transfusions or laboratory exposure) has been also described $(37,39)$.

Up to $80 \%$ of the infected people remain asymptomatic. When they do occur, clinical manifestations are generally mild and self-limiting: moderate fever $\left(37-38^{\circ} \mathrm{C}\right)$, arthralgia, myalgia, headache, conjunctivitis, centripetal pruritic erythematous maculopapular rash lasting 1-4 days.

The complications associated with the infection first attracted attention on the disease. Newborn microcephaly and other nervous system malformations are a possible consequence of infection in pregnant women. The infection was also accompanied by: Guillain-Barré syndrome, meningoencephalitis, hearing impairment, hematospermia. 11 deaths have been reported so far in connection with Zika virus infection (38).

In non-endemic areas, the disease is difficult to recognize by a mere physical examination, in the absence of solid epidemiological arguments. A positive diagnosis generally requires confirmation by molecular biology tests or by IgM antibodies determination (35).

Huaiyangshan virus is a new member of the Bunyaviridae family, which was discovered by a Chinese researcher (Xue-jieYu) in 2009 (40). It causes a severe fever syndrome associated with thrombocytopenia and digestive manifestations, with a fatality rate of up to $30 \%$. The disease, which is transmitted by tick (Haemaphysalis longicornis) bites or close contact with the patient's fluids, was reported in Eastern China (several thousand cases between 2011 and 2012). Several cases were also reported in Japan and Southern Korea (41).

\section{Other emerging diseases}

SARS was the first emerging disease of the $21^{\text {st }}$ century. An epidemic of atypical severe pneumonia cases of unknown etiology affected China in November 2002. The disease was initially exported to Hong-Kong and then rapidly spread worldwide. The first cases were reported to the WHO in February 2003 (Carlo Urbani, an Italian doctor, was the first to have recognized SARS as a new disease; he himself died due to this infection, a month later) (42), and the (SARS-CoV) virus was identified after only a few weeks in several laboratories. More than 24 countries reported cases within only a few months from the first one. Fortunately, the epidemic was extinguished by the end of 2003, with 8096 probable cases and 774 deaths reported $(9.6 \%$ fatality rate) (43).

The history of the Middle East Respiratory Syndrome (MERS) started in June 2012, with a 60-year old Saudi Arabia sheik, with no previous comorbidities, who died due to a severe febrile respiratory infection accompanied by renal failure, apparently with no etiology. A few months later, an Egyptian doctor (Ali Mohamed Zaki) announced the discovery of a new coronavirus (MERS-CoV) associated with this disease, which subsequently spread in Jordan and other countries in the region (44). Imported cases were later reported in Europe, USA, Africa and Asia. In May 2014, there were 697 confirmed cases and 210 dead (45). In 2015, an epidemic broke out in Southern Korea with 186 cases and 36 deaths (46). The number of cases reached 1841 in 2016 and affected 27 countries, with a significant fatality rate $-35 \%$.

The virus comes from bats, and camels are its natural reservoir ( $>90 \%$ of the camels in Oman have antibodies), its transmission being mainly zoonotic. Inter-human transmission is possible, sometimes causing nosocomial epidemic outbreaks (Korea, Japan, Saudi Arabia) (47). There is currently no vaccine or specific therapy. 
The recently extinguished Ebola (EVD) epidemic was one of the biggest so far, with 28,616 probable or confirmed cases and 11,310 dead. Over 10,000 patients survived the infection (48).

The virus was first described in 1976 after an African epidemic with high fatality rates (Congo 318 cases, $88 \%$ fatality rate, and Southern Sudan 284 cases, $53 \%$ fatality rate). The virus disappeared for 20 years only to reappear later in successive outbreaks in Central and Western Africa (Congo, Uganda and Gabon) (49).

The onset of the current epidemic dates back to December 2013 and was traced to Guinea. It rapidly extended to the neighboring countries Sierra Leone and Liberia, the highest number of cases being reported in the latter country (4809) (50).

The cases exported both to Europe (15 confirmed cased) and to the USA (11 confirmed cases), as well as the significant percentage of lethal cases, despite the modern supportive treatment and the experimental attempts of etiological therapy, have been a serious preoccupation for the specialists.

Disease transmission to the medical staff had been known since before this epidemic, considering that such cases had been reported during the previous outbreaks as well (in 1995 and 2000, 89 and 32 cases, respectively). The medical staff providing care to these patients are thought to be 21-32 times more predisposed to catching the disease than the general population. 1040 EVD cases were reported in the medical staff at the end of the epidemic (815 confirmed cases). Among the infected individuals, $50 \%$ were nurses and caregivers, $12 \%$ were doctors or students, laboratory personnel. Two thirds of infected medical staff died (51). At the beginning of the epidemic, over $10 \%$ of the patients belonged to this category, that had come into contact with the initial cases. According to a WHO report, in the three most affected African countries, between 1.5 and $6.9 \%$ of the entire medical staff died of EVD in the referenced period $(1.45 \%$ in Guinea, $8.07 \%$ in Liberia and $6.85 \%$ in Sierra Leone) (51).

The disease transmission path has not been fully elucidated yet, but it seems that close contact with the patient or their secretions is necessary. It is thought that local burial rituals have significantly contributed to disease spread (51).
After a 3-to-16-days incubation period, EVD manifests itself as febrile disease with digestive and respiratory symptoms. The second week is characterized either by the patient's recovery, or by the occurrence of hemorrhagiparous phenomena, multiple organ failure, diffuse intravascular coagulation and often death (49).

The diagnosis is set by PCR or viral antigen detection. The specific IgM antibodies may be detected 8-12 days after disease onset.

The international community joined forces to help the affected countries and sent over 4,000 experts in 70 locations, 1.48 millions of sets of safety equipment, logistics. Several quick diagnosis tests were developed, significant progress has been made in the creation of a vaccine and expert and rapid reaction teams in case of epidemic have been strengthen (52).

H5N1 avian influenza of 2004 was one of the first serious warnings about the pandemic risk of infectious diseases at the beginning of the third millennium. This high fatality rate $(61 \%)$ virus only spread in a few countries, most of them in South-Eastern Asia. 273 confirmed human cases were reported by 2007 (53). Although the disease has not had a large scale global spread, the antiepidemic measures (especially the killing of domestic farm poultry) had a considerable economic impact.

2009 saw the emergence of the first cases of $\mathbf{A}$ H1N1 virus influenza, initially called "swine" influenza in Mexico. It rapidly spread worldwide (214 countries, 18,499 confirmed deaths (54) and 15 times more estimated cases (55)), which determined the WHO to issue a pandemic alert. As far as Romania is concerned, almost 600 cases and 82 deaths were confirmed in 2009 and 2010. There have been controversial debates about this pandemic, the magnitude and fatality rate of which were by far inferior to those specific to seasonal influenza epidemics. There were allegations of conflict of interests and abusive behavior from certain WHO experts suspected of unorthodox connections with vaccine and influenza medicine producers (56).

A new avian influenza virus - H7N9 was detected in Eastern China in 2013, yet human cases were relatively few (419 cases, 127 dead - 22\% fatality rate). There were few exported cases - Canada, Malaysia and Hong-Kong. Inter-human trans- 
mission was possible, but difficult, an assumption proven by the few isolated family infections (57). There later occurred annual regional epidemic outbreaks, the latest and widest so far being the one affecting China between October 2016 and February 2017 , where there were 424 confirmed cases (58).

The Enterovirus 68 is another emerging pathogen. Identified for the first time in California in 1962 (59), this virus is responsible for an occasionally severe child's respiratory disease, especially in asthma patients. Only 26 cases were detected in the USA between 1970 and 2005; nevertheless, starting with 2013, epidemic outbreaks have been reported in Japan, Philippines, Netherlands and USA (60). An epidemic broke out in 49 American states and Canada between August and October 2014, with 1153 confirmed cases and 14 dead (61).

Nipah virus is responsible for a zoonosis transmitted from bats to humans, with epidemic outbreaks in Malaysia (1998-1999: 283 cases, 109 deaths) (62) and in Bangladesh, (2004), due to contaminated palm tree sap consumption, with a fatality rate of over $50 \%$ (30 confirmed cases, 18 dead) (63). The infection may be asymptomatic or cause respiratory symptoms, sometimes lethal encephalitis. The disease extended to Asia and Australia and corresponded to the bats' natural habitat; several cases were also reported in Mozambique and Ghana (64).

\section{CONCLUSIONS}

The events that occurred during the recent years have proven that there are no borders to infectious diseases, which may spread very rapidly.

The question that each local specialist should ask him or herself is whether they are theoretically and logistically ready to deal with such an emerging disease which we may be brought to face unexpectedly.

Conflict of interest: none declared Financial support: none declared

\section{REFERENCES}

1. Brasier M., McLoughlin N., Green O., Wacey D. A fresh look at the fossil evidence for early Archaean cellular life" (PDF). Philosophical Transactions of the Royal Society B. London: Royal Society. 2006; 361 (1470): 887-902.

2. Mellars $P$. Why did modern human populations disperse from Africa ca. 60,000 years ago? A new model. Proc. Natl. Acad. Sci. U.S.A. Washington, D.C.: National Academy of Sciences. 2006; 103 (25): 9381-9386.

3. Hoole S. The select works of Antony van Leeuwenhoek: Containing his microscopical discoveries in many of the works of nature. History of ecology. Arno Press. 1977

4. Capanna E. Lazzaro Spallanzani. At the Roots of Modern Biology. Journal of Experimental Zoology 1999; 285, 3:178-196

5. Aminov R.I. A Brief History of the Antibiotic Era: Lessons Learned and Challenges for the Future. Front Microbiol. 2010; 1, 134; 1-7

6. Burnet F.M., White D.O. Natural history of infectious disease. 4th edn. Cambridge: University Press, 1972

7. WHO - Fact sheet 310. 2014 http://www.who.int/mediacentre/ factsheets/fs310/en/

8. Lederberg J., Shope R.E., Oaks S.C. Emerging infections: microbial threats to health in the United States. Institute of Medicine (U.S.). Committee on emerging microbial threats to health Washington, D.C.: National Academy Press, 1992.

9. Morse S.S. Factors in the emergence of infectious diseases. Emerg Infect Dis.1996; 1(1):7-15

10. van Doorn H.R. Emerging infectious diseases. Medicine. 2014; 42, 1: 60-63

11. Jones K.E., Patel N.G., Levy M.A., Storeygard A. et al. Global trends in emerging infectious diseases. Nature 2008; 451(7181):990-3

12. Tsai T.F., Popovici F., Cernescu C., Campbell G.L., Nedelcu N.I. West Nile encephalitis epidemic in southeastern Romania. Lancet. 1998. 5; 352(9130):767-71.

13. Nash D., Mostashari F., Fin A. et al. The Outbreak of West Nile Virus Infection in the New York City Area in 1999. N Engl J Med 2001; 344:1807-14.
14. Chowers M.Y., Lang R., Nassar F. et al. Clinical characteristics of the West Nile fever outbreak, Israel, 2000. Emerging Infectious Diseases. 2001; 7(4):675-678.

15. Drebot M.A., Lindsay R., Barker I.K. et al. West Nile virus surveillance and diagnostics: A Canadian perspective. The Canadian Journal of Infectious Diseases. 2003; 14(2):105-114.

16. Carney R.M., Ahearn S.C., McConchie A. et al. Early Warning System for West Nile Virus Risk Areas, California, USA. Emerging Infectious Diseases. 2011; 17(8):1445-1454.

17. Danis A., Kostas M. et al. "Outbreak of West Nile Virus Infection in Greece, 2010." Emerging Infectious Diseases 2011,17.10:1868-1872

18. ECDC/WHO Regional Office for Europe. West Nile virus infection outbreak in humans in Romania, 2010. http://ecdc.europa.eu/en/ publications/publications/1104_mir_west_nile_outbreak_romania.pdf.

19. Sirbu A., Ceianu C.S., Panculescu-Gatej R.I., Vázquez A., Tenorio A., Rebreanu R., Niedrig M., Nicolescu G., Pistol A. Outbreak of West Nile virus infection in humans, Romania, July to October 2010. Euro Surveill. 2011;16(2). http://www.eurosurveillance.org/ ViewArticle.aspx?Articleld=19762

20. Centrul Naţional de control şi supraveghere a bolilor transmisibile (CNSCBT). Infecţia cu virusul West Nile, România, 2016. http:// www.cnscbt.ro/ index.php/informari-saptamanale/west-nile-1/586-infectia-west-nile-in-romania-la-03-noiembrie-2016

21. Smith D.W., Hall R.A., Johansen C.A., Broom A.K., Mackenzie J.S. Arbovirus Infections in Cook G and Zumla Al. Manson's Tropical Diseases, 22 ed, Ed Saunders Elsevier, 2008, 715 -751

22. ECDC. Aedes albopictus geographical distribution. http://ecdc. europa.eu/en/ healthtopics/vectors/mosquitoes/Pages/ aedes-albopictus.aspx\#C2

23. Higgs S. The 2005-2006 Chikungunya Epidemic in the Indian Ocean. Vector Borne Zoonotic Dis 2006; 6:115-116.

24. WHO. Outbreak news. Chikungunya, India. World Health Organization Weekly Epidemiological Record 2006; 81:409-416. 
25. Rezza G., Nicoletti L., Angelini R., Romi R., Finarelli A.C. et al. CHIKV study group. Infection with chikungunya virus in Italy: an outbreak in a temperate region. Lancet. 2007, 1; 370(9602):1840-6.

26. Delisle E., Rousseau C., Broche B., Leparc-Goffart I. et al. Chikungunya outbreak in Montpellier, France, September to October 2014. Euro Surveill. 2015; 20(17): 2110

27. Lindsey N.P., Prince H.E., Kosoy O. et al. Chikungunya Virus Infections Among Travelers-United States, 2010-2013. The American Journal of Tropical Medicine and Hygiene. 2015; 92(1):82-87. doi:10.4269/ajtmh.14-0442.

28. Gubler D.J. Novartis Found Symp. Dengue/dengue haemorrhagic fever: history and current status. 2006; 277:3-16;

29. Chaturvedi U.C., Nagar R. Dengue and dengue haemorrhagic fever: Indian perspective. J Biosci. 2008; 33(4):429-41.

30. Ranjit S., Kissoon N. Dengue hemorrhagic fever and shock syndromes. Pediatr. Crit. Care Med. 2011,12 (1): 90-100

31. Nimmannitya S. Dengue and Dengue Haemorrhagic Fever in Manson's Tropical diseases, 22nd Ed. 2009, 753-761

32. Gyawali N., Bradbury R.S., Taylor-Robinson A.W. The epidemiology of dengue infection: Harnessing past experience and current knowledge to support implementation of future control strategies J Vector Borne Dis, 2016, 53, 293-304

33. European Centre for Disease Prevention and Control. Dengue outbreak in Madeira, Portugal, March 2013. Stockholm: ECDC; 2014.

34. Passi D., Sharma S., Dutta S.R., Ahmed M. Zika Virus Diseases - The New Face of an Ancient Enemy as Global Public Health Emergency (2016): Brief Review and Recent Updates. International Journal of Preventive Medicine. 2017:8:6.

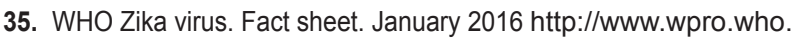
int/mediacentre/factsheets/fs 05182015 zika/en/

36. Musso D., Nilles E.J., Cao-Lormeau V.M. Rapid spread of emerging Zika virus in the Pacific area. 2014. Clinical Microbiology and Infection. 20(10):0595-6

37. Plourde A.R., Bloch E.M. A Literature Review of Zika Virus. Emerging Infectious Diseases 2016, 22, 7,1185-1192

38. Pan American Health Organization / World Health Organization. Zika - Epidemiological Report Brazil. March 2017. Washington, D.C.: PAHO/WHO; 2017

39. Musso D., Nhan T., Robin E., Roche C., Bierlaire D., Zisou K. et al. Potential for Zika virus transmission through blood transfusion demonstrated during an outbreak in French Polynesia, November 2013 to February 2014. Euro Surveill. 2014;19:20761.

40. He, C.Q. Ding, N.Z. Discovery of severe fever with thrombocytopenia syndrome bunyavirus strains originating from intragenic recombination.. Journal of Virology 2012. 86 (22): 12426-30

41. Shimojima M., Fukushi S., Tani H., Yoshikawa T., Morikawa S., Saijo M. Severe fever with thrombocytopenia syndrome in Japan. Uirusu. 2013; 63(1):7-12.

42. Preble A.M. Microarrays Enabled Discovery of the SARS Virus. Nature Education 2015, 8(2):5

43. WHO. Summary of probable SARS cases with onset of illness from 1 November 2002 to 31 July 2003. http://www.who.int/csr/sars/ country/table2004_04_21/en/

44. Banik G.R., Khandaker G., Rashid H. Middle East respiratory syndrome coronavirus "MERS-CoV": current knowledge gaps. Paediatr Respir Rev 2015; 16(3): 197-202.

45. WHO. Middle East respiratory syndrome coronavirus (MERS-CoV). Fact sheet $\mathrm{N}^{\circ} 401$, June 2015 http://www.who.int/mediacentre/ factsheets/mers-cov/en/
46. Wiwanitkit S., Wiwanitkit V. Korean MERS: A new cross continent emerging infectious disease. Asian Pac J Trop Dis 2015; 5(10): 835-836

47. World Health Organization (WHO). Middle East respiratory syndrome coronavirus (MERS-CoV) Summary of Current Situation: Literature Update and Risk Assessment, 5 December 2016 http:// www.who.int/entity /emergencies/mers-cov/merssummary-2016.pdf?ua=1

48. World Health Organization (WHO). Ebola virus disease. Situation report. 10 June 2016 http://apps.who.int/iris/ bitstream/10665/208883/1/ebolasitrep_10 Jun2016_eng. pdf?ua $=1$

49. Vâţ̧ă A, Luca MC, Dorobăţ C. Boli tropicale. Ed. „Gr. T. Popa” laşi, 2012 ISBN: 978-606-544-102-6

50. World Health Organization (WHO). Ebola virus disease. Situation report. 30 March 2016 http://apps.who.int/iris/ bitstream/10665/208883/1/ebolasitrep_1 0Jun2016_eng. pdf?ua $=1$

51. World Health Organization (WHO). Health worker Ebola infections in Guinea, Liberia and Sierra Leone. A PRELIMINARY REPORT 21 May 2015 www.who.int/hrh/documents/21may2015_web_final. pdf

52. World Health Organization (WHO). Ebola Response in Action http://apps.who.int/ebola/our-work/achievements

53. http://www.who.int/csr/disease/avian_influenza/country/en/

54. European Centre for Disease Prevention and Control (ECDC) Daily Update - Pandemic (H1N1) 2009 - 18 January 2010 http:// ecdc.europa.eu/en/ healthtopics/Documents/100118_Influenza_AH1N1_Situation_Report_0900hrs.pdf.

55. Dawood, Fatimah S. et al. Estimated global mortality associated with the first 12 months of 2009 pandemic influenza A H1N1 virus circulation: a modelling study The Lancet Infectious Diseases, 12, 9, 687-695

56. Godlee F. Conflicts of interest and pandemic flu BMJ 2010; 340 : c2947

57. Kang Yiu Lai, Wing Yiu Ng G., Kit Fai Wong et al. Human H7N9 avian influenza virus infection: a review and pandemic risk assessment. Emerging Microbes and Infections. 2013, 2, e48

58. CDC. Avian Influenza A (H7N9) Virus. https://www.cdc.gov/flu/ avianflu/h7n9-virus.htm

59. Schieble J.H., Fox V.L., Lennette E.H. A probable new human picornavirus associated with respiratory diseases. Am. J. Epidemiol 1967. 85:297-310

60. CDC Clusters of Acute Respiratory IIIness Associated with Human Enterovirus 68 - Asia, Europe, and United States, 2008-2010. Morbidity and Mortality Weekly Report (MMWR). 2011, 60(38): 1301-1304

61. Messacar K., Abzug M.J., Dominguez S.R. 2014 outbreak of enterovirus D68. North America. J Med Virol. 2016; 88(5):739-45.

62. Chua K.B. Epidemiology, surveillance and control of Nipah virus infections in Malaysia. Malaysian J Pathol 2010; 32(2) : 69 - 73

63. WHO. Nipah virus in Bangladesh http://www.who.int/csr/ don/2004_04_20/en/

64. Clayton B.A. Nipah virus: transmission of a zoonotic paramyxovirus. Curr Opin Virol. 2017;11;22:97-104 